
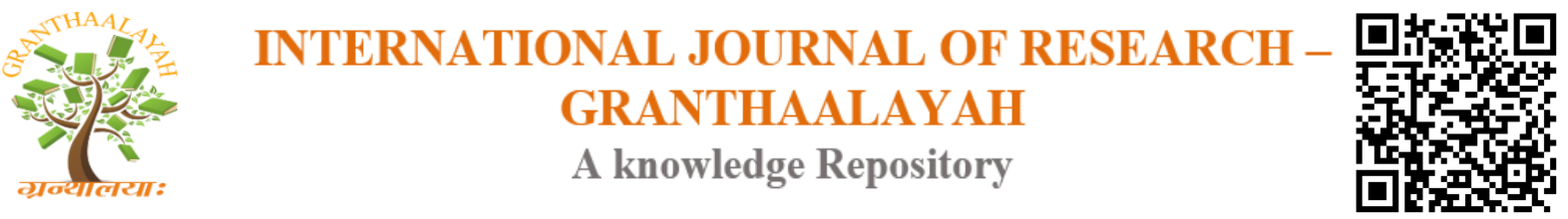

Social

\title{
DISCRIPTIVE ANALYSIS OF SOLOMAN FOUR GROUP DESIGN ON E- CONTENT IN HISTORY
}

\author{
J. Muthukumari ${ }^{1}$, Dr. N. Ramakrishnan ${ }^{2}$ \\ ${ }^{1}$ Ph.D. Research Scholar (Part-Time), Department of Educational Technology, Tamil Nadu \\ Teachers Education University, Chennai - 600 097, India \\ ${ }^{2}$ Professor and Head, Department of Educational Technology, Tamil Nadu Teachers Education \\ University, Chennai - 600 097, India
}

\begin{abstract}
Education is a product of experience - Technological tool enhances better teaching - learning process. It changes classroom dynamics also - An important outcome of e-learning is E content The quality of education depends to great extent on the quality of teachers - The scores of the post test of experimental group (e-content in history) in PT design and the post test of experimental group (e-content in history) in PPT design are high. This may be due to the effect of e-content based teaching in history subject.
\end{abstract}

Keywords: Experimental Research, Solomon Four Group Design; Descriptive Analysis; Educational Technology; E-Content; Achievement in History.

Cite This Article: J. Muthukumari, and Dr. N. Ramakrishnan. (2017). "DISCRIPTIVE ANALYSIS OF SOLOMAN FOUR GROUP DESIGN ON E-CONTENT IN HISTORY." International Journal of Research - Granthaalayah, 5(8:SE), 47-56. https:// doi.org/10.29121/granthaalayah.v5.i8(SE).2017.2248.

\section{Introduction}

Education is exclusively a human activity. Man inherits his cultural heritage from his elders in society through education. A person without education is really like a blind. In the words of Rousseau, "Plants are developed by cultivation and men by education". Education nourishes us like a mother. It directs us to the proper path like the father. Its guides us to reach our destination like a teacher.

Education is the process of facilitating learning or the acquisition of knowledge, skills, values, beliefs and habits. Education provides us with knowledge about the world. It paves the way for a good career. It helps build character. It leads to enlightenment. It lays the foundation of a stronger nation. Education makes a man complete. Education is to make desired behavioral changes among pupils. 
Education technology has great potential for improving the teaching- learning process. Educational technology is the development, application and evaluation of systems, techniques and also aids in the field of human learning. One of the important contributions of educational technology is individualized instruction, which enables to make use of self-instructional programmes. Technological tool enhances better teacher-learning process. It changes classroom dynamics also. The computer is now used as a super-teaching machine. It's use in education has been tried as an innovation and it has proved efficiency in many developed countries.

Technology in the information revolution has provided many unique benefits to instructional programs. Although traditional ways of instruction are widely accepted in teaching and learning environments, some educational institutions have started implementing computer technology as an instructional approach. Recently, information technology has been integrated into teacher education courses in many ways, such as CD-ROMs, interactive videodiscs, teleconferencing, electronic mail, and microcomputers with hypermedia/multimedia programs. Computer assisted instruction is just one of these technological applications.

Current research on technology and education open a wide field for the analysis of emergent phenomena in the process of knowledge construction. E-learning is the new trend of educational technology. Electronic learning or e- learning is general term used to refer to computer-enhanced learning. It is used inter changeably. In many respects, it is commonly associated with the field of Advanced Learning Technology (ALT) which deals with both the technologies and associated methodologies in learning using network and multimedia technologies. The term covers a wide set of applications and processes, such as web-based learning, computer-based learning, virtual classrooms, and digital collaboration. Increased preservation and reduced learning time are other benefits to students.

E-learning is one of the means of education that incorporates self motivation, communication, efficiency and technology. E-learning is a flexible term used to describe means of teaching through technology. An important outcome of e-learning is E-content. E-learning is a process and E-content is a product. With the advancement of technology in education sector, it has become important for teachers to adapt E-content and incorporating multimedia into learning. This approach of teaching has become an answer to the complicated modern, social, and economic condition and for an exploding population. There are many open source tools available these days but the only tool which is easy to use E-content. E-content is the heart of e-learning. It is the core of any single or multimedia application, whether commercial or not. E-content is delivered via the internet, intranet/extranet, audio or video tape, satellite TV, and CD-ROM. It can be self-paced or instructor led and includes media in the form of text, image, animation, streaming video and audio. E-content today is mostly viewed as a way to preserve and carry forward cultural or historical heritage, to disseminate lifestyle, scientific, educational and business information in some digitalized format, or to provide some interactive service to users.

History is learnt in schools throughout the world. It can be regarded as one of the most important subjects. The word 'history' relates to the Greek term "historia", which stands for the knowledge acquired through investigation. The world itself and everything in it is dynamic in nature. Man in this ephemeral world not only confronts big and small things but also events and experiences in which every single thing, animate and inanimate including himself, the earth, the planets and the 
rest of the universe plays a part. History is the record of these events and experiences. It acquaints the future citizens with the past and prepares a background by which they may build up their present and prepare for their future. It is the basis of all subjects of study and deals with all aspects of life - social, political, economic, cultural and religious.

History is the study of the past. In this era of modern technology, many people wonder why it is important to learn history as a subject. History is not just a subject which is studied in classrooms, but a genuine science that deals with the true origins and development of our planet and our species, following closely through the ages; ancient, medieval and modern. History involves discoveries, research and invention of new analytical methods to succeed in decoding historical facts and understanding them.

\section{Statement of the Problem}

The problem has been selected and stated as "DISCRIPTIVE ANALYSIS OF SOLOMAN FOUR GROUP DESIGN ON E-CONTENT IN HISTORY”.

\section{Important of the Study}

E-content means web - based instruction developed for individual's auto learning on any subject required by the learners. E-content is the latest method of instruction that has attracted more attention together with the concept of models. The benefits of E-content for learners are including flexible schedule and instruction at convenient locations such as houses, schools and colleges, it informs learners about their processes and accomplishment. An important outcome of E-learning is E-content. Many educational institutions have come forward to prepare e-content materials for a limited number of subjects. At the higher education level, the University Grants Commission, New Delhi has allocated funds to those who are willing to develop e-content on any subject.

The ultimate aim of e-content development is to create an information rich society where everyone, irrespective of caste, religion, race, region, gender etc., are empowered to create, receive, share and utilize information and knowledge for their economic, social, cultural and political upliftment and development. In the process of E-learning, structured and validated econtent can serve as an effective virtual teacher.

Learning through e-content encourages critical and active learning. With e-content materials, the learner and teacher will understand that he or she is changing from a provider of facts to the one who facilitates a learning environment. It is in this assumption that this investigation attempts to devise an innovative teaching technique through e-content approach. Humans can integrate information from different sensory stimuli into meaningful experiences. The effectiveness of teaching methods plays an important role in imparting the desired messages to the students. The teaching methods or the instructional strategies are dynamic and varying from time to time and target to target. To cope with the changes, the competence of the teachers has to be enhanced and enriched not only on the methods but also on the content knowledge. 
History as a subject is facing a major setback. Very few students are opting for history, as the methodology used for teaching history is still traditional chalk and talk method. Students feel it is boredom to learn the dates and various events. So, the teachers must certainly try some attractive methods to teach the subject joyfully. The technological advancement of media and communication lays emphasis on influencing people in everyday life. E-content generates excitement and enthusiasm. E-content on history will help students to get clear understanding of the subject history. In order to study the effectiveness of it, the researcher has chosen "The Beginning of Modern Age" a part in history from IX standard social science syllabus of Tamil Nadu State Government.

\section{Objectives of the Study}

The following objectives have been framed by the researcher in the present study:

1) To find out the achievement of IX standard students in the post test of experimental group (e-content in history) in PT design.

2) To find out the achievement of IX standard students in the post test of control group (Traditional learning in history) in PT design.

3) To find out the achievement of IX standard students in the pre test of experimental group (e-content in history) in PPT design.

4) To find out the achievement of IX standard students in the post test of experimental group (e-content in history) in PPT design.

5) To find out the achievement of IX standard students in the pre test of control group (Traditional learning in history) in PPT design.

6) To find out the achievement of IX standard students in the post test of control group (Traditional learning in history) in PPT design.

\section{Hypotheses of the Study}

On the basis of the objectives of the present study the investigator framed the following hypotheses:

1) The achievement scores of IX standard students in the post test of experimental group (econtent in history) is average in PT design.

2) The achievement scores of IX standard students in the post test of control group (Traditional learning in history) is average in PT design.

3) The achievement scores of IX standard students in the pre test of experimental group (econtent in history) is average in PPT design.

4) The achievement scores of IX standard students in the post test of experimental group (econtent in history) is average in PPT design.

5) The achievement scores of IX standard students in the pre test of control group (Traditional learning in history) is average in PPT design.

6) The achievement scores of IX standard students in the post test of control group (Traditional learning in history) is average in PPT design.

\section{Sample}

The sample of this study consisted of 100 IX standard students from two schools of Chennai and Tiruvallur Districts in Tamil Nadu. The sample was taken from Kesari Higher Secondary School, 
Mylapore, Chennai District and Vivekananda Matriculation Higher Secondary School, Uthukottai, Tiruvallur District in Tamil Nadu.

\section{Methodology}

Methodology is the technique or procedure adopted in a research study or investigation. Experimental method is adopted in the present study.

\section{Design of the Study}

A worthwhile research project is likely to result from a formulated research design. The design can be equated to a blue print which provides a clear cut guideline to the investigator in carry out his/her research successfully. In the present study, the investigator developed and validated econtent package on history unit "The Beginning of Modern Age". To achieve the objectives the investigator has chosen Solomon Four-Group experimental design. The students of control group were taught by traditional lecture method which includes verbal discourse, chalk and talk and text only. The students of experimental group were taught through e-content and the measures were taken to control or minimize the threats to internal and external validity to a reasonable degree.

\section{Tools used for the Study}

The following tools and materials were used in the present study:

1) Criterion test on history for IX standard students in the unit "The Beginning of Modern Age" was the major tool used to measure the dependent variable.

2) E-content package on history unit "The Beginning of Modern Age" a part in history from IX standard social science syllabus of Tamil Nadu Government.

\section{Conducting the Experiment}

In the present research the experimental method was employed. Solomon Four Group design has been used. In 'Solomon four group research design', this requires two experimental and two control groups. The groups are given below.
- Group I
- Pre-test Post -test Experimental Group
- Group II
- Pre-test Post -test Control Group
- Group III
- Post -test only Experimental Group
- Group IV
- Post -test only Control Group

The Pre-test and Post-test were administrated for both Group I and Group II. The post-test only were administrated for Group III and Group IV. The investigator had developed the e-content package for IX standard history subject. The two Experimental groups' sample of 50 students was taken to the treatment. These students were taught with the e-content way of instruction. The two Control groups' sample of 50 students was taken to the regular classroom. These students were taught in the traditional way. The treatment was given for 45 minutes per day. Corrective feedback was given wherever necessary. When any point was not learnt additional time was given and the media material was screened once again wherever necessary. 


\section{Statistical Techniques Used}

The follow statistical technique was used in the study:

- Descriptive Analysis

\section{Hypotheses Testing}

\section{Hypothesis 1}

The achievement scores of IX standard students in the post test of experimental group (e-content in history) is average in PT design.

Table 1: Descriptive Analysis for the Post Test Scores of Experimental Group (E-Content in History) in PT Design

\begin{tabular}{|l|l|l|}
\hline S.No & Description & Value \\
\hline 1 & Mean & 43.32 \\
\hline 2 & Standard Deviation & 7.66 \\
\hline 3 & Low Score & 27 \\
\hline 4 & Highest Score & 56 \\
\hline 5 & Median & 44 \\
\hline 6 & Theoretical Mean & 30 \\
\hline
\end{tabular}

It is evident from the above table that the median value of the group is 44 , the highest score of the group is 56 and the lowest score of the group is 27. The mean value obtained is 43.32 with standard deviation of 7.66. It is well above the theoretical mean of 30. It is proved from the above table that the achievement scores of IX standard students in the post test of experimental group (e-content in history) is higher than the average in PT design.

\section{Hypothesis 2}

The achievement scores of IX standard students in the post test of control group (Traditional learning in history) is average in PT design.

Table 2: Descriptive Analysis for the Post Test Scores of Control Group (Traditional Learning in History) in PT Design

\begin{tabular}{|l|l|l|}
\hline S.No & Description & Value \\
\hline 1 & Mean & 35.68 \\
\hline 2 & Standard Deviation & 9.04 \\
\hline 3 & Low Score & 23 \\
\hline 4 & Highest Score & 53 \\
\hline 5 & Median & 34 \\
\hline 6 & Theoretical Mean & 30 \\
\hline
\end{tabular}

It is evident from the above table that the median value of the group is 34, the highest score of the group is 53 and the lowest score of the group is 23 . The mean value obtained is 35.68 with standard deviation of 9.04. It is slightly above the theoretical mean of 30. It is proved from the above table that the achievement scores of IX standard students in the post test of control group (Traditional learning in history) is higher than the average in PT design. 


\section{Hypothesis 3}

The achievement scores of IX standard students in the pre test of experimental group (e-content in history) is average in PPT design.

Table 3: Descriptive Analysis for the Pre Test Scores of Experimental Group (E-Content in History) in PPT Design

\begin{tabular}{|l|l|l|}
\hline S.No & Description & Value \\
\hline 1 & Mean & 19.76 \\
\hline 2 & Standard Deviation & 5.44 \\
\hline 3 & Low Score & 11 \\
\hline 4 & Highest Score & 20 \\
\hline 5 & Median & 31 \\
\hline 6 & Theoretical Mean & 30 \\
\hline
\end{tabular}

It is evident from the above table that the median value of the group is 31 , the highest score of the group is 20 and the lowest score of the group is 11 . The mean value obtained is 19.76 with standard deviation of 5.44. It is below the theoretical mean of 30. It is proved from the above table that the achievement scores of IX standard students in the pre test of experimental group (econtent in history) is average in PPT design.

\section{Hypothesis 4}

The achievement scores of IX standard students in the post test of experimental group (e-content in history) is average in PPT design.

Table 4: Descriptive Analysis for the Post Test Scores of Experimental Group (E-Content in History) in PPT Design

\begin{tabular}{|l|l|l|}
\hline S.No & Description & Value \\
\hline 1 & Mean & 47.8 \\
\hline 2 & Standard Deviation & 7.48 \\
\hline 3 & Low Score & 29 \\
\hline 4 & Highest Score & 58 \\
\hline 5 & Median & 48 \\
\hline 6 & Theoretical Mean & 30 \\
\hline
\end{tabular}

It is evident from the above table that the median value of the group is 48 , the highest score of the group is 58 and the lowest score of the group is 29 . The mean value obtained is 47.8 with standard deviation of 7.48. It is well above the theoretical mean of 30. It is proved from the above table that the achievement scores of IX standard students in the post test of experimental group (e-content in history) is higher than the average in PPT design.

\section{Hypothesis 5}

The achievement scores of IX standard students in the pre test of control group (Traditional learning in history) is average in PPT design. 
Table 5: Descriptive Analysis for the Pre Test Scores of Control Group (Traditional Learning in History) in PPT Design

\begin{tabular}{|l|l|l|}
\hline S.No & Description & Value \\
\hline 1 & Mean & 18.88 \\
\hline 2 & Standard Deviation & 6.88 \\
\hline 3 & Low Score & 9 \\
\hline 4 & Highest Score & 35 \\
\hline 5 & Median & 19 \\
\hline 6 & Theoretical Mean & 30 \\
\hline
\end{tabular}

It is evident from the above table that the median value of the group is 19 , the highest score of the group is 35 and the lowest score of the group is 9. The mean value obtained is 18.88 with standard deviation of 6.88. It is below the theoretical mean of 30. It is proved from the above table that the achievement scores of IX standard students in the pre test of control group (Traditional learning in history) is average in PPT design.

\section{Hypothesis 6}

The achievement scores of IX standard students in the post test of control group (Traditional learning in history) is average in PPT design.

Table 6: Descriptive Analysis for the Post Test Scores of Control Group (Traditional Learning in History) in PPT Design

\begin{tabular}{|l|l|l|}
\hline S.No & Description & Value \\
\hline 1 & Mean & 36.92 \\
\hline 2 & Standard Deviation & 9.67 \\
\hline 3 & Low Score & 21 \\
\hline 4 & Highest Score & 54 \\
\hline 5 & Median & 37 \\
\hline 6 & Theoretical Mean & 30 \\
\hline
\end{tabular}

It is evident from the above table that the median value of the group is 37, the highest score of the group is 54 and the lowest score of the group is 21 . The mean value obtained is 36.92 with standard deviation of 9.67. It is slightly above the theoretical mean of 30 . It is proved from the above table that the achievement scores of IX standard students in the post test of control group (Traditional learning in history) is higher than the average in PPT design.

\section{Findings of the Study}

The major findings of the study are as follows:

1) The achievement scores of IX standard students in the post test of experimental group (econtent in history) is high in PT design.

2) The achievement scores of IX standard students in the post test of control group (Traditional learning in history) is high in PT design.

3) The achievement scores of IX standard students in the pre test of experimental group (econtent in history) is average in PPT design. 
4) The achievement scores of IX standard students in the post test of experimental group (econtent in history) is high in PPT design.

5) The achievement scores of IX standard students in the pre test of control group (Traditional learning in history) is average in PPT design.

6) The achievement scores of IX standard students in the post test of control group (Traditional learning in history) is high in PPT design.

\section{Interpretation}

The scores of the post test of experimental group (e-content in history) in PT design and the post test of experimental group (e-content in history) in PPT design are high. This may be due to the effect of e-content based teaching in history subject.

\section{Conclusion}

The present experiment brings out a clear-cut idea about the e-content based teaching and its impact among the IX standard student' achievement in history. The quality of education depends to great extent on the quality of teachers. It is a known fact that quality teachers opt for an innovation in their teaching aspect through integrating technology in the classroom instruction to give the best to student. To be effective in the classroom instruction, teacher should acquire the knowledge and skills to use the new challenges in promoting innovative teaching strategies that are student-centered, collaborative, engaging, authentic, self-directed and based on the development of higher order thinking skills with respect to handling classes for student which aim to achieve high academic standards.

\section{References}

[1] Aggarwal, J. C. (1996). Teaching of History. New Delhi, Vikas Publishing House Pvt. Ltd.

[2] Ajai S. Gaur., \& Sanjaya S. Gaur, (2006). Statistical Methods for Practice and Research (A Guide to Data Analysis Using SPSS). New Delhi, SAGE Publications India Pvt Ltd.

[3] Archana Ganesh Watkar, (2013). Effectiveness of ICT in Teaching Education: An Experimental Study. Edutracks, Hyderabad, Neelkamal Publications Pvt. Ltd, v13 n10, p25-26.

[4] Arora, K. L. (2006). Teaching of History. Ludhiana, Tandon Publications, p1-2.

[5] Best W. John., \& Kahn V. James., (2014). Research in Education. Delhi, PHI Learning Private Limited. Chennai.

[6] Diana, C. Fernandez Zalazar., \& Carlos, M. Neri, (2015). The Use of ICT by Undergraduate Students and its Relation to Learning and Study Strategies. Journal of Contemporary Educational Research and Innovations, ISSN 2250-0618, v5n1, p1-5.

[7] Durga Padhiyarm, (2014). Educational Technology. New Delhi, Cyber Tech Publication, p1.

[8] Elizabeth Joshua., \& Ancy George, (2014). Interactive Multimedia: The Pinnacle of Education. Journal of Educational Research and Extension, ISSN 0973-6190, v51(1), p22-26.

[9] Francis, A. T., \& Susan Mathew, K. (2014). Library and Web Tools for E-learning and Teaching. New Delhi, Authors press.

[10] Gagne, R. M. (1965). The conditions of learning. New York: Holt, Rinehart and Winston.

[11] Golden, S. A. R. (2016). RURAL STUDENTS'ATTITUDE TOWARDS ENGLISH AS MEDIUM OF INSTRUCTION IN HIGHER EDUCATION-AN ANALYSIS. International Journal of Research, 3, 1-10. 
[12] Golden, S. A. R. (2017). Attitude of Students and Teachers towards E-Learning-An Analysis. Recent Research in Social Science \& Humanities, 1, 5-10.

[13] Gupta, S. P. (1969). Statistical Methods. New Delhi, Sultan Chand \& Sons.

[14] Henry E. Garrett, (2014). Statistics in Psychology and Education. Delhi, Surjeet Publications.

[15] Kothari, C. R., \& Gaurav Garg, (2014). Research Methodology, Methods and Techniques. New Delhi, New Age International Publishers.

[16] Kulbir Singh Sidhu, (1984). Methodology of Research in Education. New Delhi, Sterling Publishers Private Limited.

[17] Mangal, S. K. (2016). Statistics in Psychology and Education. Delhi, PHI Learning Private Limited.

[18] Muppidathi, G. (2013). A Study on Experts' Validation of E-Content. Indian Journal of Applied Research, v3, Issue: 11, ISSN - 2249-555X, p150-151.

[19] Nagarajan, K., Srinivasan, R., \& Mary Vijayakumar, (1994). Research Methodology in Education. Chennai, Ram Publishers.

[20] Narayan Dash Biranchi, (2003). Teaching of History. Hyderabad, Neelkamal Publications Pvt. Ltd.

[21] Panneerselavam, C. (2013). Developing, Validating and Measuring the Effectiveness of EContent in the subject Social Science at Secondary Level. Thesis, Manonmaniam Sundaranar University, Tirunelveli, Tamilnadu.

[22] Rajalakshmi, R. (2015) A Study on the Development and Effectiveness of E-Content in Teaching of Biological Science Education. Ph.D Thesis Tamil University, Thanjavur.

[23] Regi, S. B., \& Golden, S. A. R. (2014). A Descriptive Study On The Role Of Consumer Psychology And Behaviour In Product Purchasing. Indian Streams Research Journal, 3 (12), 1, 6.

[24] ss

[25] Text Book for Standard Nine, (2013). TamilNadu Textbook Corporation.

[26] Thakur, K. R. (2010). Educational Development and Technology. New Delhi, Saurabh Publishing House. 